Research Article

\title{
Butterflies of the family Pieridae (Lepidoptera: Papilionoidea) of the Frio river basin, northeastern Andes of Santander, Colombia
}

\author{
Mariposas de la familia Pieridae (Lepidoptera: Papilionoidea) de la cuenca de río Frío, nororiente \\ de los Andes de Santander, Colombia
Alfonso Villalobos-Moreno ${ }^{1}$, ${ }^{(1)}$ Néstor Cepeda-Olave ${ }^{2}$ (D) , Julián A. Salazar-Escobar $^{3}$ and Juan Carlos Agudelo-Martínez ${ }^{4}$

${ }^{1}$ Director Grupo de Investigaciones Entomológicas y Ambientales-GENA. Calle 91 No. 22-104 Apto 403, Bucaramanga, Colombia. ${ }^{2}$ Grupo de Investigación en Ciencias Animales - GRICA, Universidad Cooperativa de Colombia. ${ }^{3}$ Museo de Historia Natural. Universidad de Caldas. ${ }^{4}$ Universidad Nacional de Colombia, sede Orinoquia. 隄avillalobosmo@unal.edu.co,alfvillalmo@gmail.com

\section{ZooBank: urn:lsid:zoobank.org:pub: B0867E70-05C2-4D9B-9CB4-24E3C19628D7 https: / / doi.org/10.35249/ rche.46.3.20.20}

\begin{abstract}
The sample was collected during the Characterization of wild Entomofauna of the Frio river basin jurisdiction of $\mathrm{CDMB}$, in secondary forests in an altitudinal gradient from 1,000 to 2,911 masl. 79 specimens of the family Pieridae were collected, belonging to 13 genera of which Leptophobia had 5 species, and Catasticta and Eurema had 3 species each. We obtained 22 species distributed in six sampling locations, where the highest richness of species was in Diviso Experimental Center with 12 species and Esperanza Experimental Center with 10. The analysis of the inventory quality showed a potential richness of 32.81 species, a proportion of the observed species of $67.05 \%$ and a sampling effort of $76.41 \%$. The comparison of inventories for each locality showed a certain similarity between La Nevera, La Mariana and La Judia, and fewer similarities with El Diviso. While La Esperanza had the least similarity with all the others sampling locations, which could be explained by the altitudinal distance from the other localities.
\end{abstract}

Key words: Altitudinal gradient, Colombian Andes, diversity, inventory quality, similarity.

Resumen. El muestreo se realizó durante la Caracterización de la Entomofauna Silvestre de la cuenca de río Frío del área de jurisdicción de la $\mathrm{CDMB}$, dentro de bosques secundarios a lo largo de un gradiente altitudinal desde los 1.000 hasta los $2.911 \mathrm{msnm}$. Se capturaron 79 especímenes de la familia Pieridae, pertenecientes a 13 géneros de los cuales Leptophobia tuvo 5 especies, y Catasticta y Eurema presentaron 3 especies cada uno. Se encontraron 22 especies distribuidas en las cinco localidades muestreadas, donde El Diviso presentó mayor abundancia (29) y riqueza de especies (12). El análisis de la calidad del inventario indicó una riqueza potencial de 32,81 especies, una proporción de especies observadas del 67,05\% y un esfuerzo de muestreo del 76,41\%. La comparación de los inventarios entre sitios de muestreo permitió observar cierta similitud entre La Nevera, La Mariana y La Judía, con menor proporción con El Diviso, mientras que La Esperanza presentó la menor similitud con todos los sitios de muestreo, lo cual podría explicarse por la distancia altitudinal con las otras localidades.

Palabras clave: Andes colombianos, calidad del inventario, diversidad, gradiente altitudinal, similitud.

Received 9 August 2020 / Accepted 16 September 2020 / Published online 25 September 2020 Responsible Editor: José Mondaca E. 


\section{Introduction}

The order Lepidoptera has the third highest number of species in the world, with about 200,000 species, behind Coleoptera and Hymenoptera (Forbes et al. 2018). The family Pieridae has mostly white, green, yellow, or orange colorations, many species with migratory habits and play an important role as pollinators for large groups of plants. This family of diurnal butterflies contains 70 genera, 2,000 species in the world, belonging to four subfamilies: Pseudopontiinae, Dismorphiinae, Coliadinae and Pierinae (Lamas 2004; Maes 2007; Nijhout 1991). As other butterfly groups, the family Pieridae presents high abundance, are usually easy of sample and identify, and have a stable and wellknown taxonomy, which makes them a useful bioindicator in studies of conservation, environment impact, monitoring and biodiversity (Llorente-Bousquets et al. 1996).

The knowledge of biodiversity is a powerful tool for efficient management of natural resources for those who make decisions and create public policies, promoting the sustainable development in natural ecosystems (Heller and Zavaleta 2009). Despite its importance in many regions of Colombia, a poor knowledge of biodiversity and the increasing demand of natural resources for human needs generate unfavorable expectations for the preservation of ecosystems. In the northeastern region of the Colombian Andes, which includes the departments of Boyacá, North of Santander and Santander, the conflicts between the economic development and the preservation of natural resources are frequent. The studies of the diversity of butterflies in wild zones of department of Santander are relatively recent (Casas-Pinilla et al. 2017; Villalobos-Moreno 2013; Villalobos-Moreno et al. 2012; Villalobos-Moreno and Gómez 2015; VillalobosMoreno and Salazar 2020a, b), even so, specific studies on family Pieridae are scarce (Villalobos-Moreno and Gómez 2020; Villalobos et al. 2020).

In the department of Santander, the Regional Autonomous Corporation for the Defense of the Bucaramanga Plateau (CDMB for its initials in Spanish) has worked to build an inventory of the biodiversity of representative ecosystems of the municipalities of Bucaramanga, Floridablanca and Giron, specifically the Frio river basin. This is a relatively well-preserved area with a gradient from 650 to 3,000 masl. It is considered a zone of environmental interest due to the diversity of wild flora and fauna (Brand 2004; Villalobos-Moreno 2004; Villalobos-Moreno and Salazar 2020a). The aim of this study was to describe the composition and structure of the community of butterflies of the family Pieridae from the Frio river basin in an altitudinal gradient from 1,000 to 2,911 masl, contributing to the knowledge of the lepidopterofauna of the northeastern Colombian Andes.

\section{Materials and Methods}

Study area. The Frio river basin is located to the south and southeast of Bucaramanga, capital for the department of Santander, in the northeastern of the Colombian Andes (Fig. 1). The basin has an area of 11,820 hectares $\left(118.2 \mathrm{~km}^{2}\right)$ and is $30 \mathrm{~km}$ in length approximately (Gómez-Borrero and López-Melo 2005; Ingeominas 2007). The locations studied in the Frio river basin were La Esperanza Experimental Center $\left(7^{\circ} 04^{\prime} 20.2^{\prime \prime} \mathrm{N} ; 73^{\circ} 04^{\prime} 27.0^{\prime \prime} \mathrm{W} ; 1,100\right.$ masl), El Diviso Experimental Center $\left(7^{\circ} 08^{\prime} 37.0^{\prime \prime} \mathrm{N} ; 73^{\circ} 02^{\prime} 08.6^{\prime \prime} \mathrm{W}\right.$; 1,733 masl), La Judia hill ( $\left.7^{\circ} 04^{\prime} 77.0^{\prime \prime} \mathrm{N} ; 73^{\circ} 04^{\prime} 90.6^{\prime \prime} \mathrm{W} ; 1,890 \mathrm{masl}\right)$, La Mariana farm $\left(7^{\circ} 08^{\prime} 14.1^{\prime \prime} \mathrm{N} ; 73^{\circ} 00^{\prime} 88.0^{\prime \prime} \mathrm{W}\right.$; 2,226 masl) and La Nevera ( $7^{\circ} 06^{\prime} 48.3^{\prime \prime} \mathrm{N} ; 73^{\circ} 00^{\prime} 47.6^{\prime \prime} \mathrm{W} ; 2,911$ masl). The sampling localities have secondary forests, but La Judia include a primary forest where important flora and fauna elements there has been registered, which resulted in the establishment of the Judia Regional Natural Park (Suárez 2012). 
The locations belong to the Tropical Rain Forest (bh-T by the initials in Spanish) in La Esperanza, to Low Montane Rain Forest (bh-MB by the initials in Spanish) in El Diviso, La Judia and La Mariana, and to Low Montane Very Humid Forest (bmh-MB by the initials in Spanish) in La Nevera (Holdridge 2000). Regarding the classification of Cuatrecasas (1989), the localities belong to sub-Andean Neotropical jungle (La Esperanza, El Diviso, La Judia and La Mariana) and Andean Neotropical jungle (La Nevera).
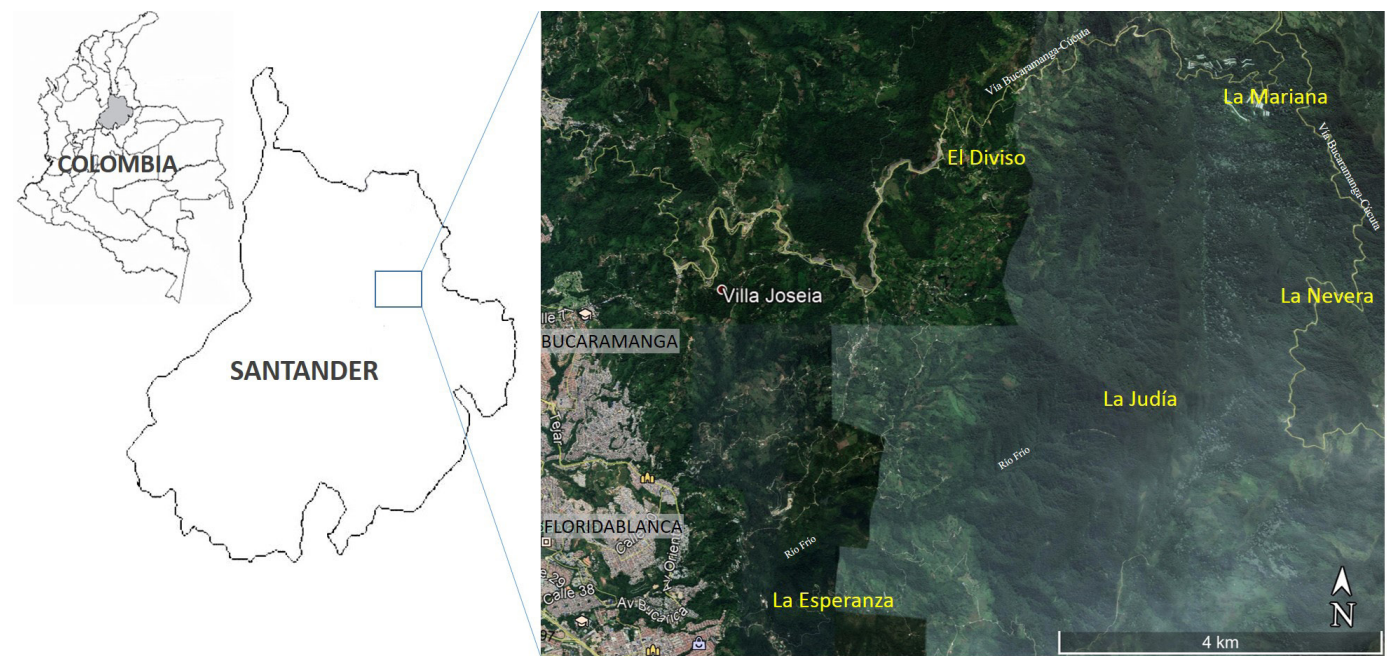

Figure 1. Location of study zone and sampling places (modified from Google Earth Pro 2020).

Sampling and identification. In each location, the sampling was carried out for 5 or 6 days, depending on the climatic conditions, from 9:00 to 17:00 hours by two collectors. The captures were made using entomological nets, within free paths of undefined length, which included forest cover, road edges and riverbanks. The collected specimens were stored in glassine envelopes and were transported to the CDMB entomology laboratory where they were mounted, labelled, and stored in Cornell boxes (Triplehorn and Johnson 2005). The butterflies were deposited in the CDMB Entomological Collection. The taxonomic identification was made with established literature (D'Abrera 1981; Le Crom et al. 2004; Salazar 2007; Villalobos-Moreno et al. 2020) and compared with specimens from CDMB Entomological Collection in Bucaramanga and Natural Sciences Institute of National University of Colombia in Bogota.

Analysis of inventory quality. We performed an analysis of sampling effort to establish the level of knowledge regarding the inventory of species and to predict the potential richness in the sampling zone. Each sampling day was considered as unit of sampling effort (USE) to, therefore, 22 USE were established. The abundance corresponded to the sum of the data of each sampling day. To avoid bias in the potential richness estimation, the data was randomized (1,000 iterations) using the EstimateS program (Colwell 2000). To predict the potential richness, the nonparametric Chao1 (based in abundance) was used. This was selected because it has been established as a robust estimator of the minimum richness and, usually, it offers better results than other estimators (Gotelli and Colwell 2001; Walther and Moore 2005). Using the CurveExpert program (Hyams 2009), estimates were adjusted to a Clench asymptotic curve, to be able calculate the different parameters of the curve (Jiménez-Valverde and Hortal 2003).

Analysis of similarity. To establish possible differences between the sampling localities 
in the Frio river basin, a matrix of presence-absence of species by sampling site was organized. Later, a grouping analysis was done to identify similarity patterns between them. The Bray-Curtis index was used as a similarity indicator and a single linkage to create the dendrogram (Ludwing and Reynolds 1988; Magurran 1988). The Past3 program was used to make the respective calculations and graphics (Hammer 2017).

\section{Results and Discussion}

In the samplings made in the five localities of the Frio river basin, 79 specimens were recorded, belonging to 3 subfamilies, 13 genera and 22 species (Table 1, Appendix 1). The subfamily Pierinae was represented by 11 species, as this is the most diverse group of Pieridae in the world; the subfamily Dismorphiinae only had 5 species, because this is considered less diverse, rarer and scarcer (Braby et al. 2006; Lamas 2004; Villalobos-Moreno and Gómez 2020). The genus with highest richness of species were Leptophobia with 5 species, followed by Catasticta and Eurema with 5 species each, which coincides in part with Henao and Stiles (2018), Murillo et al. (2018), and Sepulveda and Ramírez (2014). The localities with greater abundance were El Diviso (29), La Esperanza (18) and La Mariana (18). Likewise, the greater richness of species were El Diviso (12) and La Esperanza (10) (Fig. 2). In addition, the genera with the widest altitudinal range were Leptophobia between 1,000-2,911 masl and Colias 1,700-2,911 masl (Fig. 3). Nathalis plauta Doubleday, 1847 and Colias dimera Doubleday, 1847 were the species that fly at the highest altitude in the Frio river basin, given that some specimens were collected above 3,300 masl (Villalobos-Moreno and Mantilla 2002; Villalobos-Moreno 2020). The preliminary list of species of family Pieridae in the Frio river basin is organized based on Kristensen (1976), Scott (1985) and Llorente-Bousquets et al. (1996).

Table 1. List of species of family Pieridae in the Frio river basin. N: Abundance, CT.: Category. A: Abundant, C: Common, E: Scarce, R: Rare.

\begin{tabular}{|c|c|c|c|c|}
\hline Subfamily & Tribe & Species & $\mathbf{N}$ & CT \\
\hline \multirow{5}{*}{ DISMORPHIINAE } & & Pseudopieris nehemia (Boisduval, 1836) & 1 & $\mathrm{R}$ \\
\hline & & Dismorphia medora medora (Doubleday, 1844) & 8 & $\mathrm{C}$ \\
\hline & & Patia orise cordillera (C. \& R. Felder, 1832) & 1 & $\mathrm{R}$ \\
\hline & & Enantia melite melite (Linnaeus, 1763) & 3 & E \\
\hline & & Lieinix nemesis nemesis (Latreille, 1813) & 4 & $\mathrm{E}$ \\
\hline \multirow{6}{*}{\multicolumn{2}{|c|}{ COLIADINAE }} & Colias dimera Doubleday, 1847 & 10 & $\mathrm{C}$ \\
\hline & & Phoebis argante (Fabricius, 1775) & 4 & E \\
\hline & & Eurema albula (Cramer, 1775) & 3 & E \\
\hline & & Eurema salome (C. \& R. Felder, 1861) & 1 & $\mathrm{R}$ \\
\hline & & Eurema xanthochlora xanthochlora (Kollar, 1850) & 1 & $\mathrm{R}$ \\
\hline & & Nathalis plauta Doubleday, 1847 & 3 & E \\
\hline PIERINAE & Anthocharidini & Hesperocharis marchalii (Guérin-Méneville, 1844) & 3 & E \\
\hline
\end{tabular}




\begin{tabular}{|c|c|c|c|c|}
\hline \multirow{10}{*}{ PIERINAE } & \multirow{10}{*}{ Pierini } & Leodonta tellane tellane (Hewitson, 1860) & 1 & $\mathrm{R}$ \\
\hline & & Leodonta zenobia zenobia (C. \& R. Felder, 1861) & 2 & $\mathrm{E}$ \\
\hline & & Catasticta colla (Doubleday, 1847) & 8 & $\mathrm{C}$ \\
\hline & & Catasticta manco manco (Doubleday, 1847) & 2 & $\mathrm{E}$ \\
\hline & & Catasticta sisamus sisamus (Fabricius, 1793) & 2 & $\mathrm{E}$ \\
\hline & & Leptophobia aripa (Boisduval, 1836) & 10 & $\mathrm{C}$ \\
\hline & & Leptophobia caesia phanokia Fruhstorfer, 1907 & 3 & $\mathrm{E}$ \\
\hline & & Leptophobia eleone eleone (Doubleday, 1847) & 6 & $\mathrm{C}$ \\
\hline & & Leptophobia eleusis eleusis Lucas, 1852 & 1 & $\mathrm{R}$ \\
\hline & & Leptophobia tovaria tovaria (C. \& R. Felder, 1861) & 2 & $\mathrm{E}$ \\
\hline
\end{tabular}

The species were classified in four categories: abundant with more than 10 records, common between 6 and 10 records, scarce between 2 and 5 records, and rare with only one record (Fagua 1996; Henao 2006; Henao and Stiles 2018). None of the species collected belong to the abundant category, while the $22.73 \%$ was common, 50\% scarce and $27.27 \%$ rare. The species of the family Pieridae with the greatest abundances in the Frio river basin were Colias dimera Doubleday, 1847 (10) and Leptophobia aripa (Boisduval, 1836) (10), followed by Dismorphia medora (Doubleday, 1844) (8) and Catasticta colla (Doubleday, 1847) (8). In contrast, 6 species were considered in the rare category: Pseudopieris nehemia (Boisduval, 1836), Patia orise (C. \& R. Felder, 1832), Eurema salome (C. \& R. Felder, 1861), Eurema xanthochlora (Kollar, 1850), Leodonta tellane (Hewitson, 1860) and Leptophobia eleusis Lucas, 1852 (Table 1).

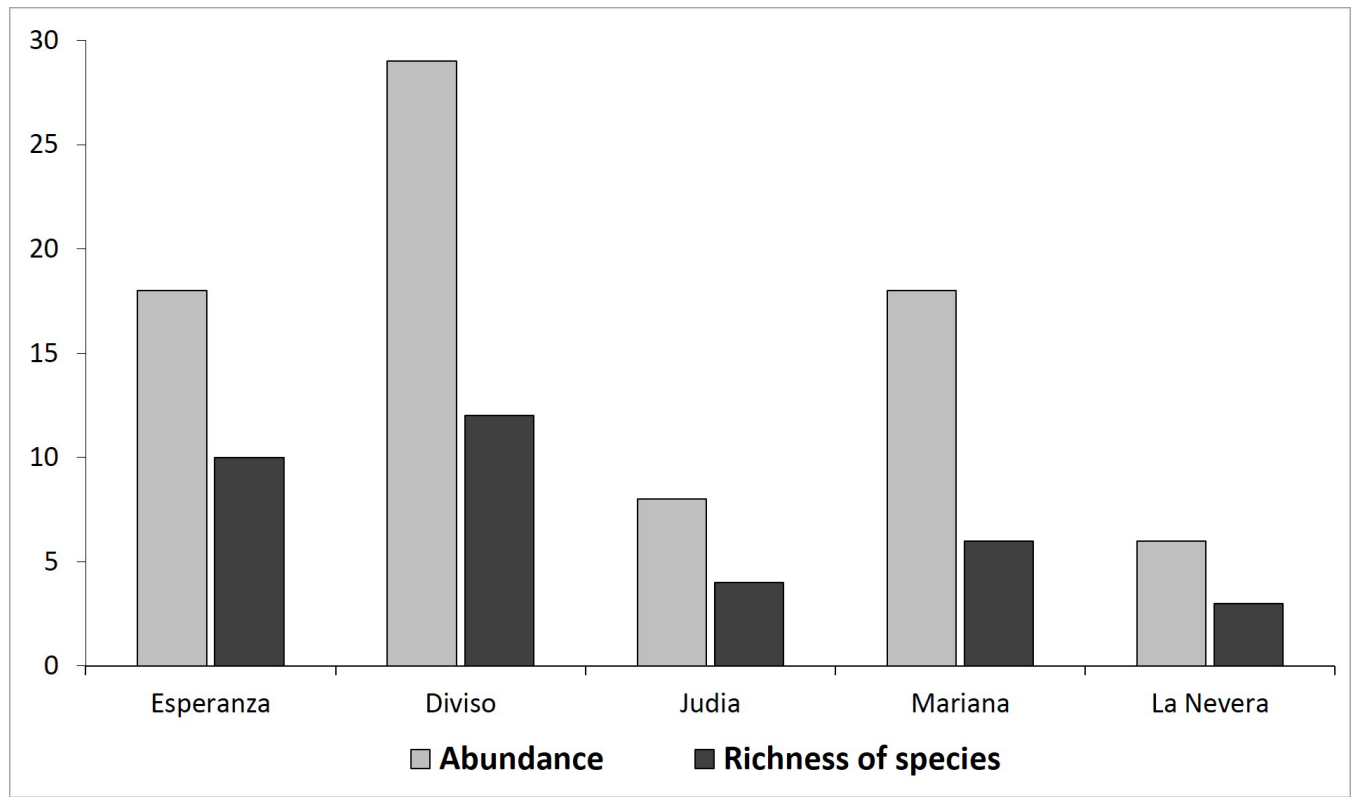

Figure 2. Abundance and richness of species by sampling sites. 


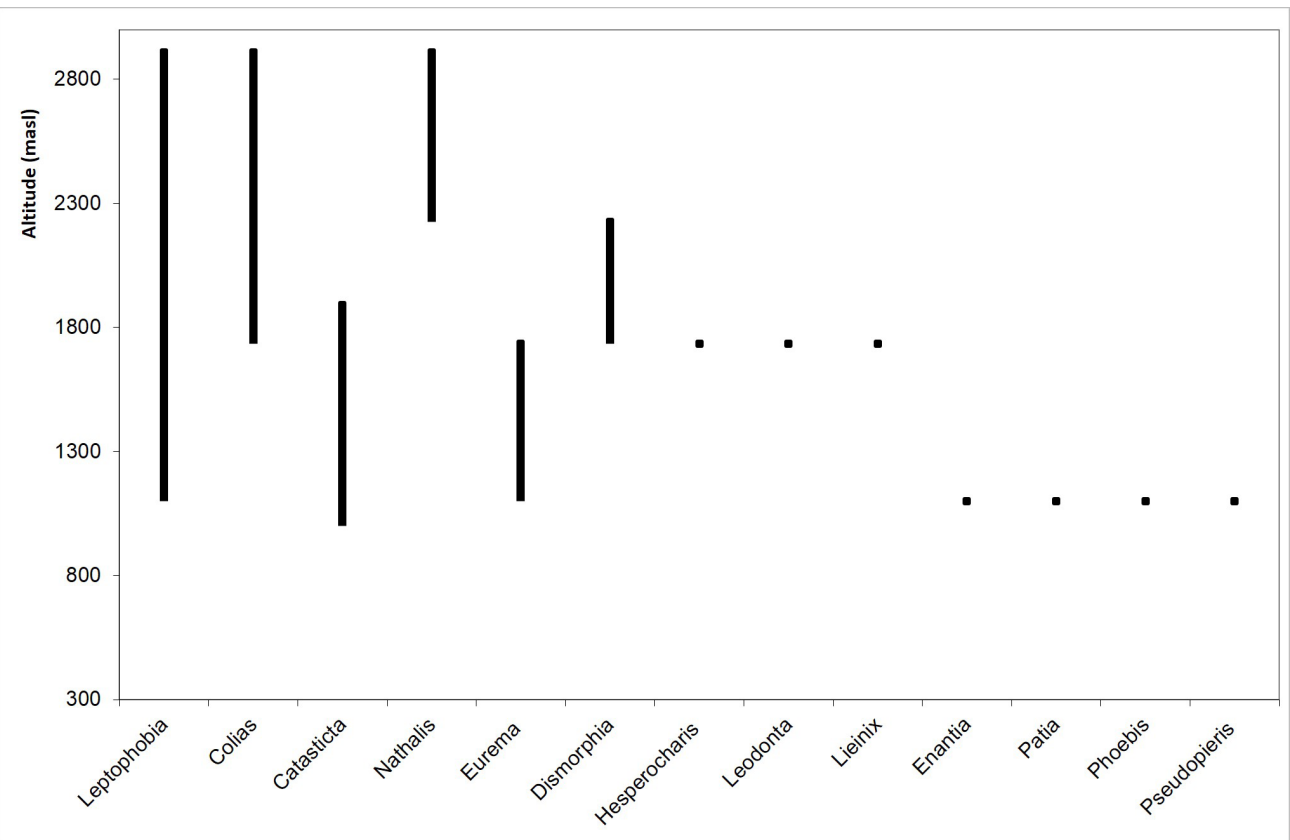

Figure 3. Altitudinal distribution of the genera of family Pieridae in the Frio river basin.

Analysis of inventory quality. The potential richness reached 32.81 species and was estimated based on the Clench curve (asymptote of the function; Fig. 4). While the slope of the curve is still high (0.27), which can be explained by the high number of single species, the proportion of observed species was $67.05 \%$ and the sampling effort estimated was $76.41 \%$, which would be considered that the inventory is relatively adequate. To obtain a more complete list of species, it is important to increase the samples in these zones and in other localities of the basin, as well as at different seasons of the year.

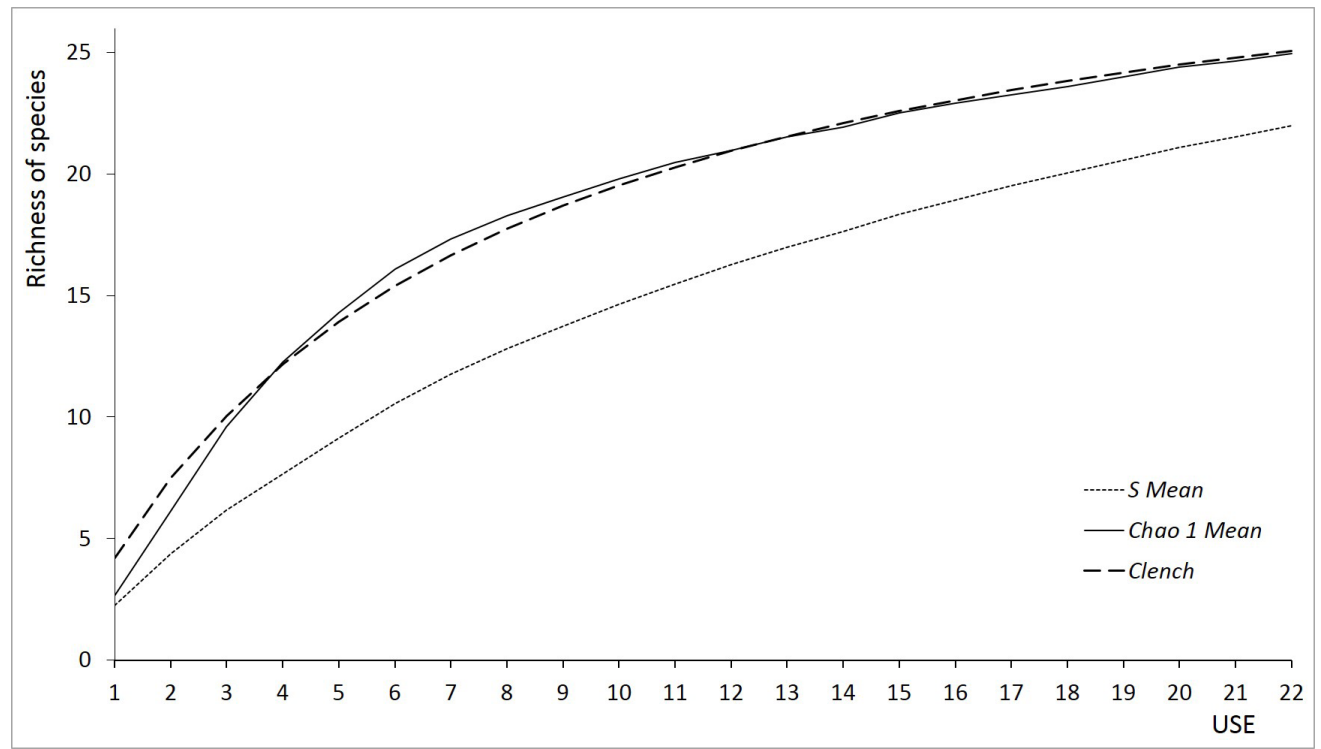

Figure 4. Analysis of sampling effort. S Mean: curve of randomized observed richness; Chao1 Mean: curve of potential richness obtained with the nonparametric estimator Chao 1; Clench: curve adjusted to the Clench asymptote $[y=(4.83 \bullet x) /(1+0.15 \bullet x)]$; standard error: 0.56 ; coefficient of correlation: 0.99 . 
Analysis of similarity. The comparison of inventories of each locality allowed the observation of a certain similarity between La Nevera, La Mariana and La Judia, and with a lesser proportion with El Diviso (Fig. 5), which could be explained by the geography and altitudinal proximity between these localities. While La Esperanza had the least similarity with all the others sampling places $(18 \%)$, which could be explained by the altitudinal distance from the other localities, as well as the proximity of increasingly growing urban areas.

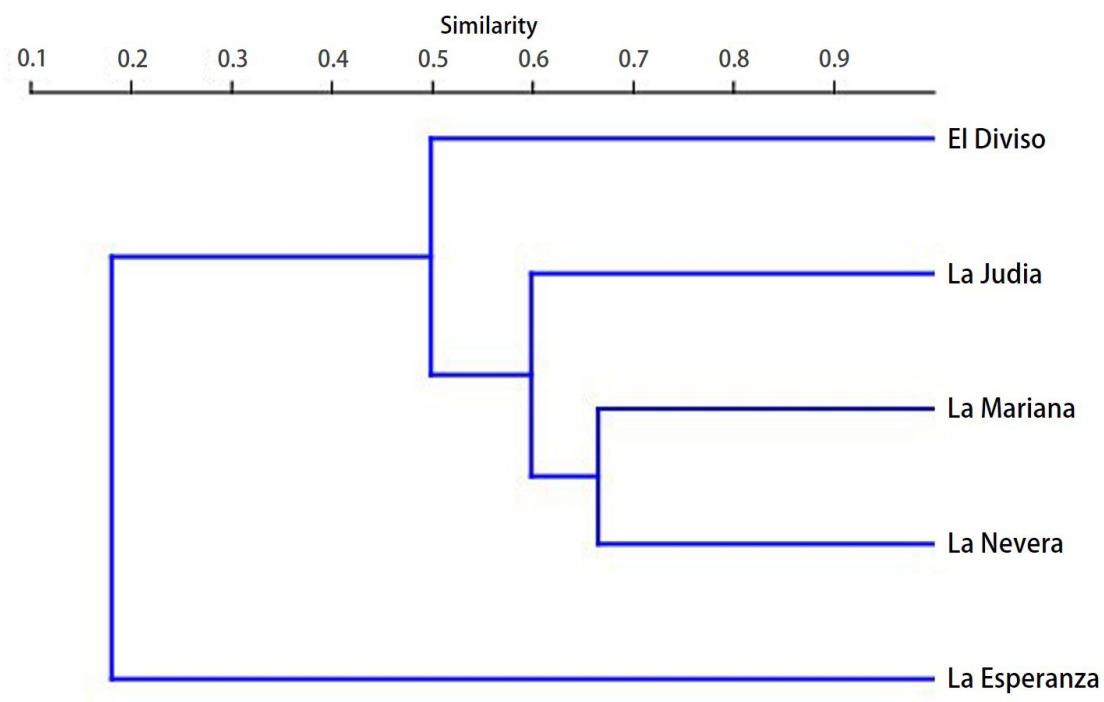

Figure 5. Analysis of similarity between locations in the Frio river basin, based in collected species of family Pieridae. Bray-Curtis index; single linkage; coefficient of correlation: 0.95 .

\section{Conclusions}

We collected 79 specimens belonging to 22 species, none of which are considered in the category abundant (more than 10 records), which may be supported by the methodology of the project, but it can also be explained by the phenology and behavior of the species. The species with greater abundances were C. dimera (10), L. aripa (10), D. medora (8) and C. colla (8), normally recorded in medium and high mountain areas. The genus with the widest altitude range was Leptophobia, and the species recorded at higher altitude were $N$. plauta and C. dimera, collected above 3,500 masl. All species are associated with conserved forest areas except for C. dimera and eventually E. albula and N. plauta, which are associated with open areas, such as paddocks and pastures. The analysis of the data shows the need for more collections in these sampled locations to obtain a complete list of species of family Pieridae for the study area. It is recommended to do more sampling in these and other locations, as well as at all season of the year.

\section{Acknowledgements}

Thanks to Gonzalo Andrade-Correa for the hospitality in the ICN-UNAL and identification support. To Julio Enrique Mantilla Serrano, Freddy Antonio Anaya and Elvia Hercilia Páez for support making the project Characterization of the Frio river basin possible. To Aldrin Darío Espinosa, Juan Carlos Hernández and Edgar Bueno for the field and laboratory work. To Gregory Nielsen, Irene Verdú, Dylan Owen and Diego Gil for the contributions to the manuscript. Infinite thanks to Daniel "Hawk" Ramírez for his invaluable contributions, without you, the science would not be possible. To Reis K. 


\section{Literature Cited}

Braby, M., Villa, R. and Pierce, N. (2006) Molecular phylogeny and systematics of the Pieridae (Lepidoptera: Papilionoidea): higher classification and biogeography. Zoological Journal of the Linnean Society, 147(2): 239-275.

Brand, J. (2004) Caracterización de la flora y la fauna de la microcuenca río Frío, municipio de Floridablanca, Santander. Corporación Autónoma Regional para la Defensa de Bucaramanga. Bucaramanga, Colombia. 72 pp.

Casas-Pinilla, L.C., Mahecha-J., O., Dumar-R., J.C. and Ríos-Málaver, I.C. (2017) Diversidad de mariposas en un paisaje de bosque seco tropical, en la Mesa de los Santos, Santander, Colombia (Lepidoptera: Papilionoidea). SHILAP Revista de Lepidopterología, 45(177): 83-108.

Colwell, R.K. (2000) EstimateS v. 6.0b1. Computer program and manual. Consulted 11 March 2020. Available at: http: / / viceroy.eeb.uconn.edu / EstimateS.

Cuatrecasas, J. (1989) Aspectos de la vegetación natural de Colombia. Pérez-Arbeláezia, 2(8): 155-289.

D`Abrera, B. (1981) Butterflies of the Neotropical Region 1: Papilionidae E Pieridae. Pemberley Natural History Books. London, UK. 172 pp.

Fagua, G. (1996) Comunidad de mariposas y artropofauna asociada con el suelo de tres tipos de vegetación de la Serranía de Taraira (Vaupés, Colombia). Una prueba del uso de mariposas como bioindicadores. Revista Colombiana de Entomología, 22(3): 143-151.

Forbes, A.A., Bagley, R.K., Beer, M.A., Hippee, A.C. and Widmayer, H.A. (2018) Quantifying the unquantifiable: why Hymenoptera, not Coleoptera, is the most speciose animal order. BMC Ecology, 18(21): 1-11.

Gómez-Borrero, E. and López-Melo, C.A. (2005) Estimación de la recarga mensual en la parte alta de la cuenca de río Frío por medio de un modelo hidrológico distribuido. Universidad Industrial de Santander. Bucaramanga, Colombia. 129 pp.

Gotelli, N. and Colwell, R.K. (2001) Quantifying biodiversity: Procedures and pitfalls in the measurement and comparison of species richness. Ecology Letters, 4: 379-391.

Hammer, O. (2017) PAST, Paleontological Statistics, version 3.18. Computer program and manual. Consulted 11 March 2020. Available at: https: / / folk.uio.no/ohammer/past/

Heller, E.N. and Zavaleta, S.E. (2009) Biodiversity management in the face of climate change: A review of 22 years of recommendations. Biological Conservation, 142: 14-32

Henao, E. (2006) Aproximación a la distribución de mariposas del departamento de Antioquia (Papilionidae, Pieridae y Nymphalidae: Lepidoptera) con base en zonas de vida. Boletín Científico Museo Historia Natural Universidad de Caldas, 10: 279-312.

Henao, E. and Stiles, F. (2018) Un inventario de las mariposas diurnas (Lepidoptera: Hesperioidea-Papilionoidea) de dos reservas altoandinas de la Cordillera Oriental de Colombia. Revista Facultad Ciencias, 7(1): 71-87.

Holdridge, L.R. (2000) Ecología basada en zonas de vida. Instituto Interamericano de Cooperación para la Agricultura. San José, Costa Rica. 216 pp.

Hyams, D. (2009) CurveExpert v1.40. Consulted 14 March 2020. Available at: http:/ / www. curveexpert.net/

Ingeominas (2007) Medición de caudales en tramos seleccionados de los ríos Tona, Frío y Oro, para evaluación de aportes de aguas subterráneas en el Macizo de Santander. Instituto Colombiano de Geología y Minería, Ministerio de Minas y Energía. Bucaramanga, Colombia. 53 pp.

Jiménez-Valverde, A. and Hortal, J. (2003) Las curvas de acumulación de especies y la necesidad de evaluar la calidad de los inventarios biológicos. Revista Ibérica de Aracnología, 8: 151-161.

Kristensen, N.P. (1976) Remarks on the family-level phylogeny of butterflies (Insecta, Lepidoptera, Rhopalocera). Journal of Zoological Systematics and Evolutionary Research, 14: 25-33. 
Lamas, G. (2004) Atlas of Neotropical Lepidoptera. Checklist: Part4A. Hesperioidea-Papilionoidea. Association for Tropical Lepidoptera. Gainesville, USA. 439 pp.

Le Crom, J.F., Constantino, L.M. and Salazar, J.A. (2004) Mariposas de Colombia. Pieridae. Carlec Ltda., Bogotá, Colombia. 113 pp.

Llorente-Bousquets, J., Luis-Martínez, A., Vargas-Fernández, I. and Soberón, J. (1996) Papilionoidea (Lepidoptera). pp. 531-548. In: Llorente-Bousquets, J., García-A., A.N. and González-S., E. (Eds.) Biodiversidad, Taxonomía y Biogeografía de los artrópodos de México: Hacia una sintesis de su conocimiento. Universidad Nacional Autónoma de México. México D.C., México

Ludwig, J.A. and Reynolds, J.F. (1988) Statistical ecology: a primer in methods and computing. Wiley-Interscience Pub. New York, USA. 368 pp.

Maes, J.M. (2007) Pieridae (Lepidoptera) de Nicaragua. Revista Nicaragüense de Entomología, 67: 1-313.

Murillo, S., Fadul, C. and Valdeleón, J. (2018) Inventario de mariposas diurnas en la cuenca de la quebrada Santo Tomás, Pensilvania-Colombia. Revista del Sistema de Ciencia, Tecnología e Innovación, 3(1): 57-76.

Nijhout, H.F. (1991) The development and evolution of Butterfly wing patterns. Smithsonian Institution Press. Washington, USA. 297 pp.

Magurran, A.E. (1988) Ecological diversity and its measurement. Princeton University Press. New Jersey, USA. 179 pp.

Salazar, J.A. (2007) Catálogo de los Rhopalocera del Museo de Historia Natural Centro de Museos-Universidad de Caldas y de la colección J. Salazar (CJS) parte I, con apuntes taxonómicos. Boletín Científico del Centro de Museos de la Universidad de Caldas, 11: 206259.

Salazar, J.A. (2020) Novedades en Historia Natural. Patia Klots un raro género de Pieridos Dismorfinos Neotropicales. Boletín Científico del Centro de Museos de la Universidad de Caldas, 24(1): 280.

Scott, J.A. (1985) The phylogeny of butterflies (Papilionoidea and Hesperioidea). Journal of Research on the Lepidoptera, 23: 241-181.

Sepúlveda, C. and Ramírez, L. (2014) Sistematización de especímenes de la familia Pieridae (Papilionoidea) del Museo de Historia Natural de la Universidad Pedagógica Nacional. Universidad Pedagógica Nacional de Colombia. Bogotá, Colombia. 80 pp.

Suárez, N.A. (2012) Plan de manejo de área protegida Parque Natural Regional Cerro La Judia. Informe técnico. Corporación Autónoma Regional para la Defensa de la Meseta de Bucaramanga. Bucaramanga, Colombia. 100 pp.

Triplehorn, C.H. and Johnson, N.F. (2005) Borror and DeLong's Introduction to the study of insects. Thomson Brooks / Cole, Gainesville, USA. 864 pp.

Villalobos-Moreno, A. (2004) Caracterización de la Entomofauna de la cuenca del río Frío, área de jurisdicción de la CDMB. Informe final. Bucaramanga, Colombia. 62 pp.

Villalobos-Moreno, A. (2013) Nueva especie de mariposa (Lepidoptera, Nymphalidae, Satyrinae) para los Andes colombianos. Boletín Científico Museo de Historia Natural de la Universidad de Caldas, 17(1): 268-275.

Villalobos-Moreno, A. (2020) Insectos de páramo en Santander. Primera Edición. Canaán Multiservicios, S.A. Bucaramanga, Colombia. 143 pp.

Villalobos-Moreno, A. and Gómez, I.J. (2015) Contribución a la distribución de las mariposas del género Morpho Fabricius, 1807 (Lepidoptera: Nymphalidae: Morphinae) en el nororiente del departamento de Santander (Colombia) y estudio de su genitalia. Boletin Científico Museo de Historia Natural Universidad de Caldas, 19(2): 281-289.

Villalobos-Moreno, A. and Gómez, I.J. (2020) Mariposas Dismorphiinae (Lepidoptera: Pieridae) en dos colecciones entomológicas del Departamento de Santander, Colombia. Boletín de la Sociedad Entomológica Aragonesa, 66(1): 261-266. 
Villalobos-Moreno, A., Céspedes-Mancilla, J.C. and Agudelo-Martínez, J.C. (2012) Mariposas (Lepidoptera: Papilionidae) de dos colecciones de Santander, Colombia. Revista Colombiana de Entomología, 38(1): 167-170.

Villalobos-Moreno, A. and Mantilla-S., J.E. (2002) Insectos de páramo y bosques de niebla, área de jurisdicción de la CDMB. Producciones Gráficas. Bucaramanga, Colombia. 49 pp.

Villalobos-Moreno, A. and Salazar-E., J.A. (2020a) Contribución al conocimiento de los Lepidoptera de la cuenca de río Frío, Santander, Colombia (Lepidoptera: Papilionoidea). SHILAP Revista de Lepidopterología, 48(189): 153-166.

Villalobos-Moreno, A. and Salazar-E., J.A. (2020b) Mariposas (Lepidoptera: Papilionoidea) de un bosque Andino en la vertiente oriental de la cuenca de río Tona, Santander, Colombia. Anales de Biología, 42: 75-84.

Villalobos-Moreno, A., Salazar-Escobar, J.A., Agudelo-Martínez, J.C. and Díaz-Olarte, J.J. (2020) Mariposas de la familia Pieridae (Lepidoptera: Papilionoidea) de un bosque seco tropical en la cuenca del río Playonero, Santander, Colombia. Revista Chilena de Entomología, 46(2): 303-312.

Walther, A. and Moore, J.L. (2005) The concepts of bias, precision and accuracy, and their use in testing the performance of species richness estimators, with a literature review of estimator performance. Ecography, 28: 815-829. 
Appendix 1. Some species of family Pieridae collected in the Frio river basin, Santander. Scale: $1 \mathrm{~cm}$.
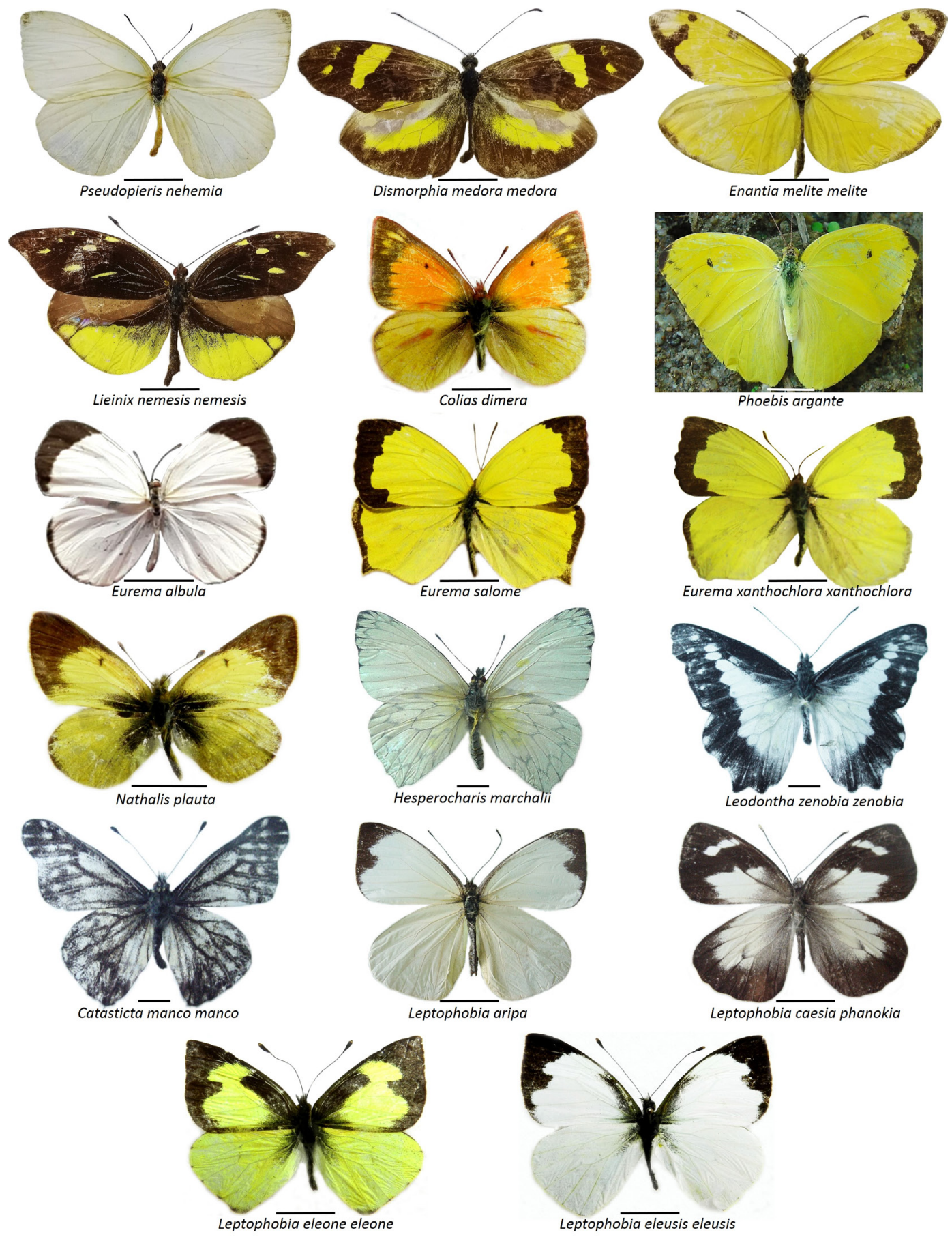